\title{
The Values of Masculinity in William Shakespeare's Macbeth
}

\author{
Mafruha Ferdous \\ Northern University, Bangladesh \\ E-mail: mafruhaferdous@yahoo.com
}

Doi:10.7575/aiac.alls.v.8n.2p.22

Received: 17/01/2017

URL: http://dx.doi.org/10.7575/aiac.alls.v.8n.2p.22

Accepted: 27/02/2017

"My strange and self-abuse / is the initiate fear that wants hard use."

Macbeth, 3.5.144-5

\begin{abstract}
The theme of gender plays a vital role in William Shakespeare's famous political play Macbeth. From the very beginning of the play the dramatist focuses on the importance of masculinity in gaining power and authority. Lady Macbeth along with the three witches are as important characters as Macbeth. Because they influence Macbeth profoundly. And Shakespeare very carefully draws the character of Lady Macbeth who being a female sometimes exhibits more masculinity than Macbeth. Similarly is the case of the three witches. Though they look like women they are also bearded which prove the presence of masculinity in their nature. Throughout the play several times the exposition of masculinity is demanded from the character of Macbeth. So the value of masculinity plays an important part in the drama.
\end{abstract}

Keywords: Masculinity, gender, prophecy, femininity, Celtic

\section{Introduction}

William Shakespeare's masterpiece "The Tragedy of Macbeth" appeared in 1606 and went down in the history of English literature just after publishing. This play is associated with conflicts of royal succession, contested theories of absolutism and the dangers of treason (Bailey 191) ${ }^{1}$. In other words, it deals with a wide variety of themes (history, traditions, war etc.), but the theme of gender roles is the main among others. The narrator focused a particular attention on the theme of manhood in women that was traditionally defined by ideas of their physical weakness, loyalty, and assertiveness. Heroic and deviant demonstration of masculinity makes readers ponder the nature of this trait. The author also managed to persuade generations of readers that masculinity was not only the feature of a male character; some women were no less masculine in their search for ambitions and power. Interrogation of the play from the perspective of some male characters who shed light on the notion of masculinity helps readers understand Shakespeare's idea about masculinity in main characters of the play.

\section{Importance of Masculinity}

Macbeth, a brave warrior, receives a prophecy that he will be the king of Scotland. Having decided not to miss a chance, he starts seizing the Scottish throne with various vile and bloody means. Such situation can serve an archetype of how power corrupts a morally immature man. Despite his merits as a warlord, this man is characterized as a tyrant and a meek husband dominated by his overbearing wife. He seems to be a hero and anti-hero. It is obvious, that this man symbolizes a blend of personal traits that used to be attributed to female, not male characters.

Exploration of the eternal question - what it means to be a male human makes readers face stereotypical ideas of masculinity. According to traditions, masculinity is always associated with brutality, aggression, and domination. Nevertheless, "The Tragedy of Macbeth" clearly demonstrates that such personal traits as cunning and an ability to reach one's goal at any price by manipulation - the features traditionally associated with women - can also fall under the category of manhood.

The play begins with the scene of prophecy given by three weird sisters to Macbeth. Although these creatures do not take part in the main action of the play, their role in "Macbeth" is very hard to overestimate. They convey prophecies to Macbeth that lead him to drastic actions and reveal the hidden dark traits of his nature. Although these witches are designed as women, their appearance and behavior enable readers to identify them rather as men. The faces of witches are covered with hair that is an allegory to their masculine natures. These witches are seen as a severe criticism of the European male-dominated culture that leaves women no chance to take an equal position in the society. Not by chance, 
these sisters hear from the lips of Banquo: "You should be women, / And yet your beards forbid me to interpret / That you are so" (Shakespeare I.2.45-47)2.

As to Banquo, he considers these witches as something foreign to the good and nature itself. In other words, he abandons himself to the idea that these witches will bring grief and woe to the world of alive people. This man demonstrates his manhood; he does not believe what they are saying. Traditionally, it is women's prerogative - to follow predictions and prophesies. Having demonstrated the force of his reason and will, this man proves his masculinity. On the contrary, Macbeth is interested in what they are saying and such curiosity breaks his life. He turns out to be a weak person, who depends on the opinion of the others.

The personality of Macbeth's wife gives readers the key to understanding female masculinity. The irony of her attempt to impose male characteristics on herself is proved by the fact that she is really trying to be a good and dutiful wife for her husband and dominate him (Kimbrough 187) ${ }^{3}$. This woman is the person who changed the history of Scotland. Terrible and fearless, she is an archetype of a Celtic woman. Her "acute mind, strong will, and a beautiful body ... full of animation and grace" (Munro 30-36) 4 give her a chance to obtain the real power behind the throne. This woman is filled with envy, greed, and hatred towards those who may prevent her husband from getting the power he never had before. Lady Macbeth can hide away her true feelings and kindness if it is necessary. But for the most of her life she pretends to be a normal lady. It is important that she means more than love for her husband. She is his ally, lover, and friend. At first glance, their marriage seems to be a union of co-equals. Nevertheless, further exploration of the play demonstrates that such picture is far from being correct.

The power of Lady Macbeth's power as a female temptress reveals that she has much in common with witches

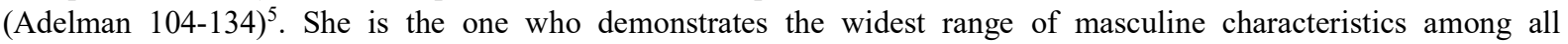
characters of the play. Having lost her newborn baby, she was afraid to lose her husband. When she learns about these prophecies, she understands that it is the only chance for her family to ascend the Scottish throne. Having read Macbeth's letter in which he described the prophecies, Lady Macbeth denies her feminine nature and gains masculine features. Despite an apparent success of such transformation, the desire of her self-masculinization contradicts the laws of nature and leads this woman to the death. This way, Shakespeare explores gender issues through the ways characters try to further themselves: men are linked to violence while women use manipulation.

The famous speech of this woman is represented in the Act I, Scene 5. The words "Come, you spirits / That tend on mortal thoughts! unsex me here, / And fill me from the crown to the toe top full / Of direst cruelty" (Shakespeare I.5.38$41)^{6}$ can be considered as the baseline of her transformation from a woman into a man. Such revocation of Lady Macbeth's female nature allows readers to have a complete idea of her conflict of identity. She invokes the evil spirits to change her gender not only psychologically but also physically. She wants to deprive herself of all the traits and physiological characteristics that can be linked to such female features as the failure for the approaching deed and weakness. Such decision is dictated by her understanding that only these features will help her to reach success in the male-dominated world. Lady Macbeth even attacks her reproductive system to eliminate any characteristics of her femininity. Soon after, she notices the thickening of her blood and elimination of her menstrual cycle. Such metamorphoses serve as a symbol of the halt of her sweet female nature that can be an obstacle from reaching the aim. An addition, this woman admits that she could kill her "only child just as easy" (Shakespeare 1.7.72-74) ${ }^{7}$. As readers can notice, Lady Macbeth has almost lost her mind in pursuing the goal of being a queen.

As these metamorphoses are not enough, she recourses to evil spirits to ask them to replace the milk in her breast with poison. The representation of such metamorphoses, an alternative form of nurturance, and its replacement with a deadly poison do not allow this woman to be considered as a human being. By doing so, she loses her soul and turns out into a frightening monster.

Lady Macbeth understands that regicide is the only way for her husband to become the king of Scotland. She encourages Macbeth to kill Duncan, the king of Scotland and uses the most sophisticated way to reach this goal. Her desire to persuade Macbeth to kill the king reveals a world of merciless persuasion and resolute purpose. She sees herself as the only catalyst of social and political change as well as the only source of masculine power (Howell 11-15). Thus, such disruption of gender roles in the tragedy is presented in the female usurpation of the dominant role in her family. Lady Macbeth took the leading position in the couple and started to dictate the actions of her husband to realize her ambitions to become a queen.

Tempted by the given prophecies, Macbeth cannot stop pondering killing Duncan. Despite his desire to become a king of Scotland, Macbeth realizes that committing regicide will be an action that would contradict the moral order of the

2. Shakespeare, W. “The Tragedy of Macbeth.” The Riverside Shakespeare. 2nd Ed. G. Blakemore Evans. Boston: Houghton Mifflin Company, 1997. Print.

3. Kimbrough R. "Macbeth: The Prisoner of Gender". Shakespeare Studies. 16. (1983): 187. Print.

4. Munro, R. "Lady Macbeth: A Psychological Sketch." The Journal of Speculative Philosophy. 21(1). 2012: 30-36. Print.

5. Adelman, J. Born of Woman: Fantasies of Maternal Power in Macbeth. Shakespearean Tragedy and Gender. Eds. 6. Shirley Nelson Garner and Madelon Sprengnether. Bloomington and Indianapolis: Indiana University Press, 1996. Print.

7. Et al. 
universe. In some sense, he is afraid that all the heaven would revolt against such actions. Nevertheless, he is blinded by such intention and corrupted by the anticipation of power. He also knows that murdering of the legal king would be a precedent and he might have the same horrible fate. Moreover, the killing of Duncan, his kin and therefore guest, would break all laws of the hospitality. Such actions will seriously break his reputation. As Macbeth rejects communal bonds and male friendship, he has no moral compass to evaluate his actions and understand whether they are the real testimony of his masculinity or not. In other words, he has no friend to consult and ask for advice. Furthermore, his wife also became an instrument of his corruption instead of being his moral compass leading him back from his errant ways and bloody actions.

Shakespeare stressed that masculinity was not achieved through male/female relationship; it is mainly constituted through male friendship. Macbeth chooses the way to exist for himself and by himself. In Act 1 Scene 7 he stands outside in the dark and ponders that treacherous act of murdering as an immoral one. Such, demonstration of the complexities of his character makes it possible to understand Macbeth's isolation from the rest of his community (Howell 19-21) ${ }^{8}$.

Lady Macbeth notices it and questions his masculinity. It should be pointed out that in standards of that epoch to accept one's cowardice means to lose one's dignity. To carry out the murder of Duncan is the only chance for Macbeth to restore his dignity in the eyes of his wife. She encourages him to be a real man: "When you durst do it, then you were a man; / And to be more than what you were, you would / Be so much more the man" (Shakespeare 1.7.49-51) ${ }^{9}$. Macbeth does not understand that she was interested in realizing her ambitions, not in the destiny of the kingdom. Her devotion to the idea of becoming the wife of the king of Scotland has evolved into obsession. Such control over the mind and soul of her husband clearly demonstrates that Lady Macbeth embodies many masculine values her husband lacks. Compelled to authenticate his masculine virtue, Macbeth capitulates to the desires of Lady Macbeth.

William Shakespeare lived in an epoch when chivalry was in decline. The depiction of Duncan's assassination proved this truth (Fröhlich 5-6) ${ }^{10}$. Having killed Duncan, Macbeth violated a chivalric code of behavior that prescribed a man to follow certain norms of behavior. Such code serves as a means to determine and measure masculinity of all men. Then he decides to kill Banquo to eliminate anybody who can prevent him from ascending the Scottish throne. Thus, Macbeth suborns the murderers to kill Banquo, his friend and comrade-in-arms, by impugning masculinity. To reach his goal, Macbeth further repudiates the masculinity of these men by comparing their behavior with the behavior of dogs. Suggesting that they lack an innate killer instinct, Macbeth taunts the murderers as Lady Macbeth taunted him not so long ago. Is the consent of the murderers to kill an innocent one be considered as the testimony of their male features? Of course, no. Moreover, such behavior always characterizes weak people whose force of will does not allow them to be considered as men. Nevertheless, the murderers agree to kill Banquo to reaffirm their masculine identity.

Since the very idea of reaffirmation of masculinity in such horrible way was wrong, all participants of this conspiracy pay for it a very high price. For example, Lady Macbeth loses her sanity the night when Duncan is murdered. Soon after she sleepwalks the corridors of the castle, keeping a candle in her hands and shakes them trying to wash away the imaginary blood of Duncan. Her unconscious verbal confession proves her implication to committing such a crime.

She realizes that the throne of Scotland her husband ascended in such way would not make him happy. Everybody remembers that he ascended the throne by killing a legal king of Scotland. This, he is a criminal, outlaw, assassin. She also understands that he did it because of her incitement. Although she told her husband "a little water clears of the deed" (Shakespeare 2.2.66) ${ }^{11}$, the action of regicide turned out to be not as easy as she used to think.

The emergence of Lady Macbeth in Act 3 in the status of Queen of Scotland makes it clear to understand that the personality of this woman was quickly deteriorated. The same can be attributed to Macbeth. He spirals out of control; his signs of paranoia become obvious. The more he tries to restore his security as a king, the less he succeeds. He distances from Lady Macbeth since he needs her advice no more. Filled with his maddening thoughts, Macbeth tells his wife that it was none of her business to know all his plans. The vision of Banquo's ghost sitting on the throne in the heat of the feast makes the madness of the king almost uncontrollable. Macbeth is the one among people who can see his former friend and comrade-in-arms. He shouts at him and Lady Macbeth forces all guests to leave their castle. This way, the masculinity of the king is also questioned since the man who turned his guests out of his door cannot be considered as a man. Despite the efforts of Lady Macbeth to provide an effective relief for her husband, he is sinking deeper and deeper into depression and destruction. In the final act of the tragedy, the torment consumes Lady Macbeth to the point of suffering where to take her own life is the only way to escape. Such tragedy of this ambitious woman is a horrible example of how rejecting one's true nature inevitably leads to the ruin of the personality. As to king Macbeth, he dies as a warrior in the fight with Macduff. This last fight was his only chance to restore his masculinity and he did it.

8. Howell M. L. Manhood and Masculine Identity in William Shakespeare's "The Tragedy of Macbeth". University Press of America, 2008. Print.

9. Et al.

10. Fröhlich V. The Construction of Femininity and Masculinity in Shakespeare`s Macbeth. GRIN Verlag, 2008. Print.

11. Et al. 


\section{Conclusion}

The core idea of The Tragedy of Macbeth is to demonstrate that when a woman replaces her feminine nature with a masculine one, it leads to a tragedy. To keep the necessary balance in one's family, a woman should be meek and kind while a man should be brave and courageous. The blending of masculine features with ambitions and thirst for blood reveals the darkest features of one's nature and is a source of evil for other people.

\section{References}

Adelman, J. Born of Woman: Fantasies of Maternal Power in Macbeth. Shakespearean Tragedy and Gender. Eds. Shirley Nelson Garner and Madelon Sprengnether. Bloomington and Indianapolis: Indiana University Press, 1996. Print.

Bailey A. Occupy Macbeth: Masculinity and Political Masochism in Macbeth. Violent Masculinities: Male Aggression in Early Modern Texts and Culture by Jennifer Feather and Catherine E. Thomas. New York: Palgrave Macmillan. 2013. Print.

Fröhlich V. The Construction of Femininity and Masculinity in Shakespeare`s Macbeth. GRIN Verlag, 2008. Print.

Howell M. L. Manhood and Masculine Identity in William Shakespeare's “The Tragedy of Macbeth”. University Press of America, 2008. Print.

Kimbrough R. "Macbeth: The Prisoner of Gender”. Shakespeare Studies. 16. (1983): 187. Print.

Munro, R. "Lady Macbeth: A Psychological Sketch.” The Journal of Speculative Philosophy. 21(1). 2012: 30-36. Print.

Shakespeare, W. "The Tragedy of Macbeth." The Riverside Shakespeare. 2nd Ed. G. Blakemore Evans. Boston: Houghton Mifflin Company, 1997. Print. 